\title{
IMPLEMENTASI KESETARAAN GENDER DAN PEMBERDAYAAN WANITA DALAM PROSES REKRUTMEN KARYAWAN
}

\author{
Suryono Efendi \\ Universitas Nasional Jakarta \\ Email: suryono.efendi@yahoo.com
}

\begin{abstract}
Abstrak
Globalisasi telah memberikan peluang bagi tenaga kerja yang lebih beragam dan pengakuan keragaman sebagai bagian integral yang esensial dari pemberdayaan. Karena tempat kerja berubah sebagai akibat dari globalisasi, teknologi, dan keragaman, para pemimpin organisasi harus mengakomodasi perubahan ini secara strategis. Pemimpin organisasi harus proaktif secara strategis untuk menjaga organisasi mereka tetap kompetitif dan sukses untuk jangka panjang dan tidak hanya bertahan di pasar yang semakin kompetitif. Artikel ini membahas bagaimana pemberdayaan dan kesetaraan gender dapat digunakan dari perspektif strategis untuk merekrut, mempromosikan, dan mempertahankan perempuan dalam angkatan kerja dan dengan demikian berkontribusi pada keberhasilan organisasi.
\end{abstract}

Kata Kunci: Pemberdayaan, Kesetaraan Gender, Promosi.

\begin{abstract}
Globalization has given more varied employees the possibility of seeing diversity as a key component in empowerment. As the workplace evolves due to globalization, technology and diversity, corporate executives must proactively adapt these changes. Organizational leaders need to be strategically proactive to retain their organisations, not just to survive in an increasingly competitive market, competitive and prosperous on the long run. This paper explores how sex empowerment and equality may be used strategically for recruiting, promoting, retaining women and so helping to achieve organizational success.
\end{abstract}

Keywords: Empowerment, Gender Equality, Promotion.

\section{A. PENDAHULUAN}

Wanita memberikan perspektif bisnis yang baru dan beragam ke pasar yang sangat kompetitif. Faktanya, penelitian menunjukkan bahwa investasi pada perempuan menghasilkan keuntungan sosial dan ekonomi yang besar (Lai \& Sarkar, 2017). Yao dkk. (2013) mendefinisikan pemberdayaan sebagai proses meningkatkan persepsi self-efficacy orang lain. Ini berarti memberdayakan karyawan untuk mengenali dan bertindak berdasarkan kemampuan dan motivasi diri mereka masing-masing. Ini juga melibatkan promosi pemikiran inovatif dan penyambutan ide-ide baru. Penelitian lebih lanjut menunjukkan bahwa konsep kepemimpinan transformasional mempromosikan harga diri dan kepercayaan diri dan mendorong karyawan untuk menjadi pemikir diri sendiri daripada menciptakan ketergantungan kepemimpinan (Handoko \& Tjiptono, 1996). Selain itu, kepemimpinan transformasional melibatkan mengubah nilai-nilai dan prioritas pengikut dan memotivasi mereka untuk melakukan melampaui harapan mereka. Menurut Tucunan dkk. (2018) Transformasi terjadi dengan cara pemimpin dan pengikut saling mempromosikan ke tingkat yang lebih tinggi dalam motivasi 
dan moralitas, ketika satu atau lebih individu terlibat dengan orang lain (Sugiono \& Efendi, 2020).

Melihat pemberdayaan dari perspektif gender, para pemimpin perlu memasukkan konsep-konsep ini ke dalam manajemen strategis organisasi mereka masing-masing (Hubeis, 2011). Makalah ini membahas bagaimana kesetaraan dan pemberdayaan gender dapat dimanfaatkan dari perspektif manajemen strategis untuk mempromosikan dan mempertahankan perempuan dalam angkatan kerja. Muslikhati (2004), menekankan bahwa demokrasi tidak pernah diberikankan tetapi harus diperjuangkan. Oleh karena itu, adalah kewajiban perempuan untuk menegaskan harapan mereka akan pemberdayaan, sebagaimana kewajiban warga negara untuk menegaskan harapan mereka terhadap demokrasi.

Dalam hal mencapai pertumbuhan dan profitabilitas, perempuan memainkan peran penting dalam organisasi publik dan swasta (Farida, 2019). Selain dampaknya terhadap organisasi, pekerjaan perempuan juga berdampak pada tingkat nasional. Misalnya, "kontribusi perempuan terhadap pertumbuhan ekonomi Indonesia cukup signifikan. Dengan meningkatkan partisipasi angkatan kerja perempuan sebesar $25 \%$ pada tahun 2025, Indonesia dapat menciptakan tambahan \$62 miliar dalam kegiatan ekonomi (sekitar 890 triliun Rupiah) dan meningkatkan PDB sebesar 2,9 persen. Selain itu, mengingat dua pertiga dari populasi perempuan di Indonesia saat ini berada dalam kelompok usia produktif 15-64 tahun, ada potensi besar untuk memacu pertumbuhan ekonomi dengan mengidentifikasi hambatan partisipasi perempuan.

Tidak terpenuhinya potensi perempuan secara signifikan menghambat pertumbuhan ekonomi (Sitorus, 2016). Satu studi menunjukkan bahwa "tingkat pendidikan dan pekerjaan yang lebih rendah untuk perempuan bertanggung jawab atas (sekitar) perbedaan 1,6\% dalam pertumbuhan PDB tahunan antara Asia Tenggara dan Asia Timur. Menurut Robert Zoellick, Presiden Bank Dunia, kesetaraan gender merupakan ekonomi yang cerdas. Perempuan dianggap sebagai sumber daya penting dalam transformasi organisasi karena mereka adalah sumber cara kreatif dan imajiner untuk beradaptasi dengan keadaan yang berubah (Rumilah \& Laili, 2019). Perempuan bertindak sebagai katalis untuk menyarankan solusi untuk masalah organisasi internal serta tanggapan terhadap perubahan yang dihasilkan dari dampak kekuatan lingkungan makro.

\section{B. METODE}

Studi ini menggunakan metodologi kualitatif untuk melakukan tinjauan literatur epistemologis tentang topik mengaktifkan dan memahami gender saat merekrut perempuan ke dunia kerja. Penggunaan desain kualitatif yang didukung oleh literatur yang menunjukkan bagaimana memperoleh pengetahuan itu atau, dengan kata lain, bagaimana memperoleh pengetahuan itu melalui prosedur, apa yang merupakan pengetahuan sejati, apa yang merupakan kebenaran, apa yang merupakan kebenaran dan bagaimana kebenaran, teknik, dan apa yang dilakukan. artinya membantu dalam memperoleh pengetahuan yang disebut sebagai sarana pengetahuan (Sugiyono, 2011). 


\section{HASIL DAN PEMBAHASAN}

\section{Kesetaraan Gender dalam Bangsa dan Organisasi}

Saat ini, para pemimpin organisasi menggunakan teknologi paling inovatif untuk mengotomatisasi proses, memangkas biaya, dan bertindak lebih cepat daripada pesaing. Strategi pemberdayaan perempuan ini juga menjadi fokus dalam memenangkan persaingan (Febrianty dkk, 2020. Fokus besar dalam strategi perusahaan saat ini adalah merekrut individu paling berbakat di pasar. Menurut laporan World Economic Forum Global Gender Gap (2017), negara-negara Nordik di Eropa seperti Islandia, Finlandia, Norwegia, dan Swedia adalah empat negara teratas yang menunjukkan kesetaraan terbesar antara pria dan wanita. Amerika Serikat berada di posisi kedelapan puluh lima dalam hal kesenjangan kesetaraan gender yang tampaknya mencerminkan tingkat penerimaan perempuan di tempat kerja. Dari Indonesia Business Coalition for Women Empowerment (IBCWE) pada keterlibatan perempauan dalam sub sector ekonomi dan kesempatan berusaha, Indonesia menempati peringkat 68 dari 153 negara. Terjadi peningkatan yang cukup signifikan. Peningkatan ini didasarkan oleh lonjakan jumlah perempuan yang memegang peran-peran penting dan posisi atas di bidang kepemimpinan sebesar 55 persen.

Kesetaraan gender mengarah pada perbaikan dalam praktik kerja, peningkatan tingkat pendidikan bagi perempuan, pengurangan kesenjangan upah dan partisipasi perempuan dalam struktur pengambilan keputusan di tingkat politik (Gap, 2017). Klaus Schwab, Pendiri dan Ketua Eksekutif Forum Ekonomi Dunia membuat pernyataan tentang kesetaraan gender yang harus dipertimbangkan oleh para pemimpin negara dan organisasi: "Kesenjangan gender yang rendah berkorelasi langsung dengan daya saing ekonomi yang tinggi. Perempuan dan anak perempuan harus diperlakukan sama jika suatu negara ingin tumbuh dan makmur. Kami masih membutuhkan revolusi kesetaraan gender yang sejati, tidak hanya untuk memobilisasi kumpulan besar talenta baik dari segi volume maupun kualitas, tetapi juga untuk menciptakan sistem nilai yang lebih welas asih di semua institusi kami” (Schwab dkk., 2017).

Terlepas dari temuan dari laporan kesenjangan gender global forum ekonomi Dunia, ketidaksetaraan gender masih ada di seluruh negara. Organisasi gagal memanfaatkan bakat perempuan dalam angkatan kerja. Sebuah studi dilakukan oleh World Economic Forum Corporate Gender Gap untuk pertama kalinya pada tahun 2010 untuk menilai dan menganalisis alasan perdebatan yang sedang berlangsung mengenai kesenjangan gender dan posisi perempuan di perusahaan mereka. Studi tersebut didasarkan pada tanggapan dari 600 kepala Sumber Daya Manusia dari 20 negara terbesar di dunia. Studi tersebut mencakup, "penggunaan praktik kesetaraan gender seperti pengukuran dan penetapan target, kebijakan keseimbangan kehidupan kerja dan bimbingan serta pelatihan". Temuan studi menunjukkan bahwa sebagian besar organisasi tidak memiliki kebijakan kesetaraan gender (Zahidi \& Ibarra, 2010).

Pemimpin organisasi ingin menarik orang-orang dalam angkatan kerja yang memiliki gelar paling bergengsi, pendidikan lanjutan, dan/atau mereka yang memiliki pengalaman kerja yang bereputasi baik. Strategi untuk sebagian besar menggunakan teknik konvensional dan mencari kandidat ini di ruang pasar yang dikenal yang mencakup papan pekerjaan, posting pekerjaan, database resume, dan jaringan sosial yang menargetkan kandidat yang mencari pekerjaan. Pemimpin organisasi mencoba untuk mempertahankan struktur biaya yang efisien. Untuk mencapai hal ini, menjadi sangat penting bagi para pemimpin organisasi untuk 
memberdayakan dan memotivasi karyawan yang ada sehingga mereka ingin sukses, terus membangun karir dan akhirnya tetap di dunia kerja (Muslimah, 2019).

Rhode (2017) mencatat, walaupun perempuan membentuk hampir setengah dari angkatan kerja, hanya sekitar 80 orang dari eksekutif puncak di antara perusahaan Fortune 500 adalah perempuan. Pada penelitian sebelumnya studi McKinsey \& Company menemukan bahwa 53\% wanita berada pada level entry sedangkan $14 \%$ berada pada posisi komite eksekutif di organisasi perusahaan (Barsh \& Yee, 2011). Hal ini penting dari perspektif penghematan biaya dalam memanfaatkan pemberdayaan untuk mempromosikan dan mempertahankan perempuan dalam angkatan kerja sangat penting untuk struktur biaya yang efisien. Strategi ini akan dibahas secara lebih rinci di bawah, dan kemudian diikuti oleh tantangan yang dihadapi pengusaha dalam mencoba mempertahankan bakat wanita, meningkatkan kepuasan karyawan, dan menjadi perusahaan pilihan.

\section{Strategi Implementasi Kesetaraan Gender melalui Pemberdayaan}

Efek keragaman pada kinerja organisasi bervariasi dan terpisah. Mendukung atau mempromosikan keragaman yang lebih besar dalam kelompok kerja membantu karyawan untuk lebih memahami organisasi mereka masing-masing. Pasar yang beragam berfungsi sebagai sampel untuk populasi yang lebih besar dan dengan demikian memberikan kemampuan yang lebih baik untuk menembus margin yang lebih besar dari berbagai pasar (Shinta, 2011). Demikian pula, Dewi (2017) menunjukkan bahwa keragaman dalam sistem pengambilan keputusan institusional berarti terlibat dalam perjuangan yang terkait dengan tujuan bisnis, tetapi potensi hasil yang menguntungkan dalam budaya kerja baru membuat semuanya berharga.

Untuk mempromosikan dan mempertahankan wanita di angkatan kerja, organisasi harus fokus pada konsep pemberdayaan dan fleksibilitas untuk mendorong wanita agar mau membangun karir dan menginginkan mobilitas ke atas dalam jangka panjang. Karyawan wanita berjuang di tempat kerja untuk berkembang secara bersamaan dalam karier dan kehidupan keluarga mereka. Memanfaatkan gagasan fleksibilitas sebagai pendekatan strategis untuk memberdayakan perempuan adalah win-win solution bagi pengusaha dan karyawan perempuan. Dari perspektif internal, ini akan mendukung peningkatan produktivitas dan inovasi, kepuasan dan retensi karyawan, penghematan biaya yang direalisasikan. Saat ini, wanita mencari fleksibilitas dalam karir mereka, dan inisiatif fleksibilitas memungkinkan pengusaha untuk mempertahankan bakat wanita mereka dan perspektif yang beragam tentang. Juga dari perspektif eksternal, pemberdayaan dan fleksibilitas akan menarik wanita paling berbakat di angkatan kerja, sehingga memposisikan diri mereka sebagai pemberi kerja pilihan. Selain memberdayakan perempuan dengan cara menerapkan gagasan fleksibilitas ke dalam budaya organisasi, pemimpin organisasi harus fokus mempertimbangkan konsep pemberdayaan saat melakukan riset bisnis (Sukoco \& Dewi, 2019).

Saat ini, banyak organisasi memiliki tim peneliti yang ditunjuk yang berfungsi atas nama mereka dalam berbagai cara. Riset bisnis dapat digunakan untuk menentukan perubahan dan dampaknya terhadap organisasi. Ini dapat mencakup menangkap informasi tentang apa yang memotivasi dan memberdayakan beragam anggota angkatan kerja. Dalam persaingan konvensional, perusahaan menimbang gaji, dan tunjangan. Namun, dalam kompetisi era 4.0, penelitian dilakukan dengan kerangka berpikir inovatif, yang menangkap ide-ide baru, dan 
menciptakan cara untuk memotivasi dan memberdayakan karyawan dan dengan demikian berdampak positif terhadap kepuasan karyawan.

Saat meneliti beragam komposisi tenaga kerja, ini harus mencakup perbedaan generasi dan gender selain kecerdasan bisnis. Peneliti harus menentukan prioritas "kehidupan" apa di luar pekerjaan yang dapat meningkatkan kepuasan karyawan. Jika dijalankan secara efektif, strategi ini berpotensi mengurangi turnover perempuan secara sukarela, yang meningkatkan efisiensi struktur biaya. Akibatnya, organisasi dapat memposisikan diri mereka untuk menjadi perusahaan pilihan bagi kumpulan bakat wanita di pasar. Ini akan menjadi cerminan langsung dari pengejaran tanpa henti dari upaya individu untuk mengamankan posisi yang mendukung gagasan fleksibilitas (Darsono, 2002).

Ada banyak manfaat yang terkait dengan konsep keseimbangan kehidupan kerja. Tunjangan-tunjangan ini memiliki efek domino di mana ketika karyawan mendapat manfaat, majikan, pada gilirannya, akan mendapat manfaat. Misalnya, ketika individu puas dengan kariernya, individu tersebut akan berusaha mempertahankan kariernya karena komponen kehidupan kerja sangat bermanfaat. Ketika ini terjadi, ada manfaat khusus bagi pemberi kerja termasuk "peningkatan produktivitas, sebesar 50 persen atau lebih, peningkatan kepuasan karyawan terkait dengan peningkatan kepuasan pelanggan, retensi, dan profitabilitas, pengurangan absensi dan biaya pergantian.

Peningkatan area kinerja ini memberikan peluang bagi organisasi untuk berkembang di industri dan mendapatkan keuntungan yang lebih tinggi. Manfaat lain yang khusus bagi pemberi kerja adalah bahwa ketika sebuah organisasi tumbuh di masing-masing bidang kinerja ini; itu bekerja menuju menjadi majikan pilihan. Ini terutama benar ketika kepuasan karyawan dan kepuasan pelanggan meningkat. Ini menarik lebih banyak individu berbakat dan oleh karena itu karyawan berkualitas lebih tinggi yang ingin bekerja untuk organisasi dengan reputasi ini. Menarik bakat memberi perusahaan keuntungan kompetitif di pasar. Untuk mencapai keseimbangan kehidupan kerja, pemimpin organisasi harus menempatkan karyawan wanita mereka "dalam posisi yang lebih meningkatkan peluang dalam perusahaan sehingga mereka dapat memanfaatkan atau memanfaatkan bakat mereka dan meningkatkan kemungkinan menaiki tangga perusahaan" Keseimbangan kehidupan kerja berdampak langsung pada organisasi dalam banyak cara positif, memungkinkan peluang bagi organisasi untuk memposisikan diri dengan lebih baik untuk pertumbuhan dan kesuksesan dalam lingkungan yang kompetitif saat ini.

\section{Tantangan Organisasi ke Depan}

Pemimpin organisasi strategis fokus pada mempromosikan perspektif bisnis yang beragam di tempat kerja. Ini adalah upaya kompetitif karena tempat kerja yang beragam telah dikenal untuk menemukan ide-ide baru dan menggabungkan perspektif yang beragam dalam pengambilan keputusan. Dalam hal pemberdayaan dan inisiatif keseimbangan kehidupan kerja, pengusaha harus mempertimbangkan banyak variabel. Pertama, persepsi "kehidupan" untuk satu individu mungkin sangat berbeda untuk individu lain yang mungkin memiliki latar belakang budaya yang berbeda Tenaga kerja yang beragam secara budaya saat ini dapat menghadirkan tantangan dalam mendefinisikan apa yang dianggap sebagai prioritas "kehidupan" bagi individu dari budaya yang berbeda. Selanjutnya, pemimpin organisasi tidak hanya harus melihat populasi karyawan mereka saat ini. Mereka juga harus 
mempertimbangkan tenaga kerja secara keseluruhan dan menganalisisnya dari perspektif keragaman dibandingkan dengan strategi keragaman perusahaan masing-masing dalam hal pertumbuhan (Nurhayati, 2014). Dari perspektif kompetitif, pemimpin organisasi juga harus melihat ke arah mana tenaga kerja dipimpin. Membangun strategi dalam hal tenaga kerja hari ini tidak akan cukup besok. Saat ini, organisasi melakukan outsourcing proyek dan bekerja tidak hanya untuk tenaga kerja yang lebih murah tetapi juga untuk bakat dan inovasi yang tepat (Efendi dkk, 2020).

Eksekusi strategi sangat penting bagi pemimpin organisasi yang harus membuat keputusan strategis yang tepat dan mengambil tindakan strategis yang tepat. Dalam hal merancang strategi yang sukses, eksekusi harus dipertimbangkan dari sudut pandang strategis dan taktis. Selain itu, tidak kalah pentingnya adalah keselarasan dengan strategi baru dari tingkat eksekutif secara vertikal dan horizontal di seluruh organisasi. Tantangannya adalah membuat para manajer "tradisionalis" bergabung. Sebuah organisasi mungkin menerima dorongan dari personel manajemen dan non-manajemen karena beberapa orang menolak perubahan. Misalnya, jika seorang manajer tidak mendukung inisiatif kesetaraan gender, bawahan langsungnya mungkin ragu-ragu dalam mengambil keuntungan dari berbagai program yang ditawarkan perusahaan karena khawatir pengukuran kinerja mereka (termasuk penilaian kinerja) akan berdampak negatif. Agar inisiatif kesetaraan gender menjadi yang paling efektif, efisien, dan dilaksanakan secara maksimal, karyawan manajemen dan nonmanajemen harus beradaptasi dengan perubahan budaya organisasi ini.

Kim (2005) membahas konsep yang sangat penting dari "Proses Adil". Memanfaatkan konsep proses yang adil sangat penting ketika menjalankan strategi karena karyawan ingin dan perlu memahami tujuan di balik strategi serta apa peran mereka setelah strategi diterapkan. Terlepas dari tingkat, jenis kelamin, atau karakteristik demografis lainnya, karyawan ingin merasa dihargai dan dihargai di lingkungan kerja mereka. Salah satu cara untuk memastikan bahwa pemenuhan emosional ini tercapai bagi wanita adalah bagi pemimpin organisasi untuk mendorong keterlibatan karyawan wanita dalam tim. Dengan cara ini, mereka dapat berpartisipasi dalam diskusi dan keputusan yang dibuat sehubungan dengan strategi baru. Sekali lagi, keterlibatan ini sangat penting bagi keberhasilan strategi pemberdayaan dari perspektif kesetaraan gender. Pemimpin organisasi harus memastikan bahwa prinsip proses yang adil termasuk dalam pelaksanaan dan implementasi strategi baru untuk kesetaraan gender. Hal ini akan mendorong para pemimpin organisasi untuk lebih berkomitmen dan terinspirasi untuk melakukan pemberdayaan sebagai strategi kesetaraan gender.

\section{KESIMPULAN}

Karena industri terus menjadi semakin mengglobal dan lebih beragam, penting bagi para pemimpin organisasi untuk menyesuaikan tujuan, strategi, dan budaya organisasi mereka untuk memasukkan kesetaraan gender agar dapat bertahan dan berkembang dalam lingkungan yang kompetitif saat ini. Makalah ini berfokus pada mempertahankan perempuan di tempat kerja melalui promosi kesetaraan gender di setiap tingkat organisasi. Organisasi yang menerapkan inisiatif kesetaraan gender akan memiliki posisi yang lebih baik untuk bersaing di pasar yang semakin kompetitif. Pemimpin organisasi dapat menjalankan strategi pemberdayaan dan kesetaraan gender dengan menerapkan fleksibilitas ke dalam budaya organisasi, kebijakan, dan praktik terbaik. Promosi dan pemberdayaan perempuan akan 
mendorong mereka untuk tetap bekerja. Hal ini dapat mengarah pada kemajuan perempuan dan pemanfaatan strategi yang paling efektif untuk menciptakan perubahan yang berkelanjutan dalam organisasi.

\section{DAFTAR PUSTAKA}

Barsh, J., \& Yee, L. (2011). Unlocking the full potential of women in the US economy. McKinsey \& Company, (April).

Darsono, L. I. (2002). Transformasi Organisasional dan MSDM: Hambatan dan Implikasinya pada rekrutmen dan seleksi. Jurnal Manajemen dan Kewirausahaan, 4(2), 77-90.

Dewi, S. K. S. (2017). Konsep Dan Pengembangan Kewirausahaan Di Indonesia. Deepublish.

Efendi, S., Sugiono, E., Guritno, E., Sufyati, \& Hendryadi. (2020). Building Innovation and Competitiveness For Low Technology Manufacturing Smes Through Imitating Capability And Learning: The Case Of Indonesia. Cogent Social Sciences, 6(1), 1803515.

Farida, D. N. (2019). Pengaruh Diversitas Gender Terhadap Pengungkapan Sustainability Development Goals. Jurnal Akuntansi Indonesia, 8(2), 89-107.

Febrianty, F., Revida, E., Simarmata, J., Suleman, A. R., Hasibuan, A., Purba, S., ... \& Saputra, S. (2020). Manajemen Perubahan Perusahaan Di Era Transformasi Digital. Yayasan Kita Menulis.

Gap, G. G. (2017). World economic forum. Cologny/Geneva.

Handoko, H., \& Tjiptono, F. (1996). Kepemimpinan Transformasional dan Pemberdayaan. Jurnal, JEBI.

Hubeis, A. V. S. (2011). Pemberdayaan Perempuan Dari Masa ke Masa. Bogor: IPB Press.

Kim, W. C. (2005). Blue Ocean Strategy: From Theory to Practice. California Management Review, 47(3), 105-121.

Lai, Y. C., \& Sarkar, S. (2017). Gender Equality Legislation and Foreign Direct Investment. International Journal of Manpower.

Muslikhati, S. (2004). Feminisme dan Pemberdayaan Perempuan Dalam Timbangan Islam. Gema Insani.

Muslimah, M. (2019). Rekrutmen Strategi Dalam Manajemen Sumber Daya Manusia. AtTa'lim: Kajian Pendidikan Agama Islam, 1(1), 31-47.

Nurhayati, S. (2014). Mambangun Kepemimpinan Yang Efektif Untuk Meraih Keunggulan Kompetitif Organisasi. Jurnal Ekonomi Dan Bisnis, 15(2), 21-27.

Rhode, D. L. (2017). Women and Leadership. Oxford University Press.

Rumilah, S., \& Laili, U. F. (2019). Penguatan Ekonomi Perempuan: Pendekatan dan Metode Pemberdayaan. Surabaya: Uinsby.

Schwab, K., Samans, R., Zahidi, S., Leopold, T. A., Ratcheva, V., Hausmann, R., \& Tyson, L. D. (2017, March). The Global Gender Gap Report 2017. World Economic Forum.

Shinta, A. (2011). Manajemen Pemasaran. Universitas Brawijaya Press.

Sitorus, A. V. Y. (2016). Dampak Ketimpangan Gender Terhadap Pertumbuhan Ekonomi di Indonesia. Sosio Informa, 2(1).

Sugiono, E., \& Efendi, S. (2020). Leadership Style, Work Discipline, and Compensation to Employee Performance through Job Satisfaction. ENDLESS: International Journal of Future Studies, 3(2), 47-63.

Sugiyono. (2011). Metode Penelitian Kuantitatif Kualitatif dan R\&D. Bandung: Alfabeta.

Sukoco, I., \& Dewi, R. (2019). Analisis Budaya Organisasi Pada Level Manajemen Puncak Di PT X Medan Sumatera Utara. AdBispreneur: Jurnal Pemikiran dan Penelitian Administrasi Bisnis dan Kewirausahaan, 3(2), 143-151. 
Tucunan, R. J. A., Supartha, W. G., \& Riana, I. G. (2014). Pengaruh Kepemimpinan Transformasional terhadap Motivasi dan kinerja Karyawan. E-jurnal ekonomi dan Bisnis Universitas Udayana, 3(09), 533-550.

Yao, Q., Chen, R., \& Cai, G. (2013). How Internal Marketing Can Cultivate Psychological Empowerment and Enhance Employee Performance. Social Behavior and Personality: An International Journal, 41(4), 529-537.

Zahidi, S., \& Ibarra, H. (2010, November). The Corporate Gender Gap Report 2010. Geneva, Switzerland: World Economic Forum. 